\title{
The radial artery for coronary artery bypass grafting
}

Citation for published version (APA):

Gaudino, M. F. L. (2020). The radial artery for coronary artery bypass grafting. [Doctoral Thesis, Maastricht University]. ProefschriftMaken. https://doi.org/10.26481/dis.20201201mg

Document status and date:

Published: 01/01/2020

DOI:

10.26481/dis.20201201mg

Document Version:

Publisher's PDF, also known as Version of record

\section{Please check the document version of this publication:}

- A submitted manuscript is the version of the article upon submission and before peer-review. There can be important differences between the submitted version and the official published version of record.

People interested in the research are advised to contact the author for the final version of the publication, or visit the DOI to the publisher's website.

- The final author version and the galley proof are versions of the publication after peer review.

- The final published version features the final layout of the paper including the volume, issue and page numbers.

Link to publication

\footnotetext{
General rights rights.

- You may freely distribute the URL identifying the publication in the public portal. please follow below link for the End User Agreement:

www.umlib.nl/taverne-license

Take down policy

If you believe that this document breaches copyright please contact us at:

repository@maastrichtuniversity.nl

providing details and we will investigate your claim.
}

Copyright and moral rights for the publications made accessible in the public portal are retained by the authors and/or other copyright owners and it is a condition of accessing publications that users recognise and abide by the legal requirements associated with these

- Users may download and print one copy of any publication from the public portal for the purpose of private study or research.

- You may not further distribute the material or use it for any profit-making activity or commercial gain

If the publication is distributed under the terms of Article $25 \mathrm{fa}$ of the Dutch Copyright Act, indicated by the "Taverne" license above, 


\section{SUMMARY}


Chapter 2. In this study, endothelial-dependent vasorelaxation to acetylcholine as well as quantitative structural analysis of the endothelial integrity were performed in open and endoscopic harvested radial arteries using a more contemporary approach. Our study showed for the first time that open radial artery harvesting is associated with better preservation of the endothelial function compared to the endoscopic harvesting.

Chapter 3. To contribute to the diffusion of use of the radial artery as a coronary artery bypass conduit, we described the results of the 20-year prospective follow-up of our initial cohort of 100 patients who received a radial artery graft for myocardial revascularization. In our series, the radial artery patency rate in the group of patients who reached the 20 -year follow-up was $84.8 \%$, with a perfect patency rate of $72.7 \%$. The status of the graft remained substantially stable in the very long term, with only 2 occlusions occurring between the 10- and the 20-year control studies in the group of patients who underwent both. Overall, the long-term patency rate of the radial artery was not statistically different than that of the gold-standard internal thoracic artery.

Chapter 4. To overcome the limitations of individual studies in detecting differences in clinical outcomes, a patient-level meta-analysis of randomized trials comparing radial-artery grafts vs saphenous-vein grafts for coronary artery bypass grafting was performed. The use of radial-artery grafts was associated with a significantly lower risk of the composite of death, myocardial infarction or repeat revascularization and of the individual risk of myocardial infarction and repeat revascularization at a mean follow-up of 5 years. The use of radial-artery grafts was also associated with superior angiographic patency rates at protocol-defined angiography, which offers a biologically mechanistic explanation of the observed improvement in clinical outcomes. 
Chapter 5. This study assesses whether calcium channel blocker use after radial artery coronary artery bypass grafting affects the midterm clinical and angiographic outcomes by pooling individual patient data from multiple randomized controlled trials. The use of calcium channel blocker was associated with a significantly lower risk of major adverse cardiac events and higher radial artery patency rate. We also found that duration of calcium channel blocker use for at least one year was associated with a reduction of clinical events and graft occlusion compared to shorter treatment and that diltiazem and amlodipine were associated with a similar protective effect.

Chapter 6. In this manuscript, we use a large patient-level dataset including six angiographic randomized controlled trials of coronary artery bypass grafting conduits to explore the incidence and determinants of coronary graft failure. With 1091 patients and 2281 grafts at a mean followup of $65 \pm 29$ months and a re-angiography rate of almost $72 \%$, our Radial Artery Database International ALliance (RADIAL) database is one of the largest and the most complete coronary graft angiographic databases. The results of our analysis show that the failure of the left internal mammary artery to left anterior descending bypass is a very uncommon event, so that even with a large patient sample, it was not possible to define independent risk factors for it.

Chapter 7. We performed a network meta-analysis with the aim to specifically investigate the differences in late survival (primary outcome) and other clinical outcomes according to the type of second graft used for coronary artery bypass grafting. The use of the radial artery or the right internal thoracic artery is associated with a similar and statistically significant long-term clinical benefit compared to the saphenous vein. There are no differences in operative risk or 
complications between the two arterial conduits, but deep sternal wound infection remains a concern with bilateral internal thoracic artery when skeletonization is not used. 